\title{
Renewable Energy (RE) and Theory on Business Sustainability: Malaysia Policy Development
}

\author{
Zeittey Karmilla Kaman, Siti Fatihah Salleh, Waznatol Widad Mohamad Ishak
}

\begin{abstract}
Sustainable energy is described as energy that meets the present demand without jeopardizing the needs of future generation. Sustainable development of energy has become the main focus of recent national policies, strategies and development plans of many countries. Renewable energy $(R E)$ is brought to play as it is deemed sustainable and has the potential to thrive in the vastly competitive market of contemporary business. Growing deployment of $R E$ resources in businesses will provide an impetus to accelerate the drive towards clean energy as well as interest and funding for research and development works. In Malaysia, RE was introduced into the energy mix through the Five Fuel Diversification Policy in 2000 and its share has been growing ever since. This article offers a critical analysis of the developing theories linking environmental sustainability to businesses practice, and discusses their implications on Malaysia's policy development toward RE. The extensive review presented in this work offers a useful reference for policy makers, corporate managers and researchers who have vested interest in business sustainability and renewable energy related studies.
\end{abstract}

Keywords:Sustainable Development; Business Sustainability; Renewable Energy; Malaysia Policy Development

\section{INTRODUCTION}

$\mathrm{S}_{\mathrm{u}}$ ustainable energy is a belief in which human consumption of energy meets the present demand without jeopardizing the needs of future generations. It is indisputable that the growing concern over energy security, environment and climate change are triggering a worldwide transformation towards cleaner energy resources and energy efficiency. RE is regarded one of the desirable source of energy that if used efficiently, would optimize energy consumption and minimize environmental impact. Government in many countries has started to review their policies to accommodate a transition to RE sources. The decision to decarbonize the energy sector would also require transformative change of energy systems towards a broad portfolio of RE industry development. A stable market for RE must be created to ensure its sustainability [1]. Besides

Revised Manuscript Received on September 22, 2019.

* Correspondence Author

Zeittey Karmilla Kaman*, Institute of Energy Policy and Research (IEPRe), Universiti Tenaga Nasional, 43000 Kajang, Selangor, Malaysia. Email: zeittey@uniten.edu.my

Siti Fatihah Salleh, Institute of Energy Policy and Research (IEPRe), Universiti Tenaga Nasional, 43000 Kajang, Selangor, Malaysia. Email: Siti.Fatihah@uniten.edu.my

Waznatol Widad Mohamad Ishak, Institute of Energy Policy and Research (IEPRe), Universiti Tenaga Nasional, 43000 Kajang, Selangor, Malaysia. Email: waznatol.widad@uniten.edu.my that,continuous efforts and strong support from the societies are also vital to ensure RE development can reach its maximum potential. This include the support from business, investor and market players in order to make RE industry popularized and consequently could generate large-scale impacts, which is equally important to the technical aspects [1].

\section{A. Problem statement}

The topic of RE association with firms is receiving growing attention from scholars. Although REis a favorable option to energy development, reducing their price to a competitive level remains a major challenge. Most commonly in current practice, government subsidies are provided to lower down the true cost of $\mathrm{RE}$ and to enable market penetration, or alternatively, traditional energy sources are penalized for not fulfilling societal goals through internalizing their external costs [2]. A study by [3] to examine the behavioral and structural factors that affect the investors and market players decisions has revealed that the beliefs on technical effectiveness of the investment and business opportunity especially related to the reliability of RE technology play a much more important than market beliefs. However, in order to create a more viable and efficient market, appropriate policy instruments should be adopted. The study also discovered that market players and investorshave a strong preference toward short term return with high level of financial incentives for limited time rather than a long-term return guaranteed by moderate and stable support in longer time. The resultsmay be relevant for practitioners in sustainable energy market globally. However, there is still lack of studies that critically analyze this strand of research related to the impacts of sustainability strategies on customers and buying decisions [4].

\section{LITERATURE REVIEW}

\section{A. Sustainability Towards RE}

Protecting the natural ecosphere by preserving the capability of environment to support human life is one of the developing processes that will lead to sustainable energy program and future-proof business. Malaysia is a strong believer and supporter of environmental debate with regard to sustainable development towards green economy. Since Malaysia's economy is shifting from material production to manufacturing, the government must play a big role in ensuring that economic growth is not happening at the expense of environment. Once the government's agenda and 
policy are made clear, business organizations and market players should cooperate and work togetherto achieve sustainableeconomic development and gain wide variety of socioeconomic and environmental benefits[5].

Renewable energy seems to give an opportunity to minimize environmental impact of the energy sector and promote the sustainable development strategy [6]. Current energy planning scenario has multiple objectives, definitions and criteria making it more difficult to attain a system with a perception of sustainability [7]. Thus, an adequate planning system encompassing necessary political, social, economic and environmental aspects is essential to overcome the rising demand of energy with a vision of sustainable development [7]. However, sustainable development as a term and concept that came into mainstream global agenda has been rigorously evolve and interpreted from a strictly Western-centric value system [8], [9]. There are approximately three hundred definitions of "sustainability" and "sustainable development" [10]. One of the sustainable development definitions is referring to development which meets the needs of the present without compromising the ability of future generation to meet their own needs [11], [12]. Generally, it emphasizes sustainability concerns that promote the indefinite existence of human systems. This concept has played a critical role in sustainable of firms as well since firms are the productive resources of the economy in a country

As a coherent description, these sustainable development theories have evolved and a series of theories have been proposed and continues to emerge to explore the relationship between sustainability, environment and firms. The major theories that have been identified were Corporate Social Responsibility, Stakeholder Theory, Corporate Sustainability and Green Economy [4]. This may pose challenges to firms in Malaysia as they adopt sustainable practice involving implementation of RE technologies and green environment into their operation.

\section{B. Corporate Social Responsibility (CSR) Towards RE}

The theory of corporate social responsibility (CSR) has been associated with firms and society since early 1953 by Howard Bowen. He defined the term "social responsibilities of businessmen" as the obligation of businessmen to pursue the policies, to make the decisions or to follow the lines of action which are desirable in terms of the objectives and value of local society. The basic idea then was to achieve a common market that would promote and increase the awareness of social responsibility among businessmen. Since then, the term "social responsibility of businessmen" gradually evolved to "corporate social responsibility" [13]. Moving onward, the concept evolved and there is a deceptive relationship between corporate social performance, economic and financial performance for a firm [14]. The purpose of a profit-making firm is to maintain or increase the wealth of its owner in the long run. However, CSR is likely requiring critical assessment of the firms' practice and principle.

For example, the established and large firms that became a critical center of market power where it might invest in CSR does not necessarily mean investing in the firm's core business. As such activity might look like cost incurred but it might also reveal to cost opportunity for saving in the form of enhancing the understanding of the business environment and decreasing the risk of conflict. Thus, the strategies and action of the firms might significantly influence the lives of society in various aspects. This is because the improvement of reputation from the public and the business community enhancing the firm's ability to attract more capital and investors [15]. Therefore, increasing global awareness of sustainability issues and CSR require the firms to include CSR practices and principle in their business strategies. The negligence to do so could result in a loss of business opportunities and competitive advantage [14], [16].

\section{Stakeholder Theory Towards RE}

The stakeholder approach and theory has been introduced by Freeman in 1984 through his book known as Strategic Management - A Stakeholder Approach. The book states that stakeholder is any group or individual who can be affected by the achievement of the organization's objective. In the development of organizational strategies, firms must realize their responsibility and understand the relationships with not only traditional stakeholder groups such as suppliers, customers, and employees, but also nontraditional stakeholder groups such as government, environmentalists, and special interest groups to manage their organizations more effectively. Each of stakeholder group may cause conflict since both parties have different sets of expectations.

Therefore, any strategic process which reduces potential conflict, such as the stakeholder management process and environmental management for the businessoperation should be extremely beneficial to the organization and its stakeholders [4], [17], [18]. It shows that the long-term survival of the firm is significantly affected with the stakeholder approach. Moreover, the stakeholder approach also implicit component of relationship marketing [17] whereby stakeholders as actors in social environment and should respond to pressures and demands from the business environment in order to attain overall strategic objectives. The concept keeps evolving since the initial stakeholder definition being too broad and argued until various aspects of stakeholder theory has been moved from conceptual to empirically investigated such as managerial perceptions of stakeholder [19], and relationship between stakeholder management and shareholder value [20].

However, shifting toward green economic environment nowadays for instance RE implementation, energy efficiency and energy conservation, would critically require the stakeholder's involvement to make binding decisions upon their interest and gain mutual benefit between them and the organization. The failure to make an effective engagement with stakeholders would drive the surpassed outcome as per targeted. For instance, a study by [21] to examinethe involvement of stakeholder in sustainable renewable energy application in Cameroon showed that the lack of responsibility from beneficiary communities, limited amount of knowledge and expertise and reduction of access to financial viability were among 
the main causes of failure in the system imposed and inoperative circumstances between both stakeholders and organizations.

\section{Corporate Sustainability Towards RE}

The past few years have brought an exponential increase in references to corporate sustainability (CS) and sustainable strategies as mentioned by [4].Parallel to this movement, CS is becoming the incumbent theory that faces a massive challenge to tackle the corporate performance in balancing the economic, environmental and social dimensions. Typical definition of corporate sustainability is adapted from Brundtland Report where sustainable development are said to have a crucial role in managing impacts of population in ecosystems, ecosystem resources, food security and sustainable economies [22], [23]. On the other hand, there are scholars, [24] and [25] who suggested that CS is a strategy that seeks the utilization of the best business practices to meet and balance the need of social, environmental concern and also the expectation of stakeholders. The concept then keep developing through the Triple Bottom Line (TBL) concept that has been introduced by [26] with the inclusion of social, environmental and financial dimensions as well. Even though TBL approach has gain wider support [27], [28], there are also some researchers out there thatcriticize the usefulness of TBL [29] due to the impossibility to reconcile the pressure between sustainability and expected profit.

\section{E. Green Economy Towards RE}

Governments in many countries have started to review their energy policies to accommodate a transition to RE sources as a response to international commitments to sustain a good quality of environment. The concept of green growth was brought into this context by focusing on changing the policy environment for firms specifically. Green economy and green growth have been recognized and discussed for the for the first time in 1989 by famous economist Pearce who suggested the environment and economy necessarily interact towards each other. Since then, the definition has been improvised and The Organization for Economic Cooperation and Development (OECD) [30] defined green economy asthe set of activities which produce goods and services to measure, prevent, limit, minimize or correct environmental damage to water, air and soil, as well as problems related to waste, noise and ecosystems.

\section{DISCUSSION AND FINDINGS}

Malaysia is one of the most developed countries among the Association of Southeast Asian Nation (ASEAN) members. It has soared like an eagle, evolving into high technology, steady economic progression, politically stable toward a maturity government and rapid infrastructural development. Besides, Malaysia also a country with harmonious and peaceful living environment with abundant natural resources and intermingle of various ethnic races through mutual understanding and tolerance. However, as the demographic changes into dramatic population increase and industrial growth, it contributes to rise in energy demand and consumption [31]. Malaysia's primary energy supply is expected to grow at $2.8 \%$ per year, from $65.9 \%$ Mtoe in 2005 to $130.5 \%$ Mtoe in 2030 which is driven mainly from the demand for coal and gas in the electricity generation sector and oil products in the transport sector [31].

In the Eleventh Malaysia Plan 2016-2020, green growth will be fundamental shift in how Malaysia sees the role of natural resources and the environment in its socio-economic development by protecting both development gains and biodiversity at the same time[32]. A green economy has an inner relationship with a clean energy policy [33] and the first sector that related is green economy assuredly is RE [34]. The Malaysian government recognized the potential of $\mathrm{RE}$ as an alternative to ensure the sustainability of energy resources and also in boosting the economy development. Thus, to support this green growth, a few strategies and instruments had been embarked on internal processes to identify and develop specific area of green opportunity to encourage the expansion of environmental goods and serviced sectors. For instances, Iskandar Regional Development Authority (IRDA) had set up to plan, promote and facilitate the development of Iskandar Malaysia (IM) where pursuing green economic zone to enable sustainable business operation and drive the Green Economy Guideline including energy efficiency, renewable energy and green procurement for nine sectors and became a global hub for green industries.

Although RE has been introduced since 2001 through the Five Fuel Diversification Policy, Malaysia still heavily depend in fossil fuels and only $2 \%$ of the power mix comes from RE to generate electricity. Therefore, the government has to internalize the effectiveness of its current policy to spur RE development in this country and remove the unnecessary barriers. This is becoming more important than ever since the government just announce a new target to achieve $20 \%$ of renewable energy in energy mix by 2025 [35]. Taking a glimpse back in the history, the National Energy Policy has been introduced in 1979 to address issues of energy production, distribution and consumption.After that, a series of policy to introduce RE and support the development of indigenous energy resources were enforced including Five Fuel Diversification Policy in 2001, National Biofuel Policy in 2006, National Green Technology Policy in 2009, and National Renewable Energy Policy and Action Plan.in 2010. Under these policies, various initiatives, programs and activities have been implemented including Green Technology Financing Scheme, Renewable Energy Business Fund (REBF), and most notably -Feed in Tariff (FiT) Scheme and Large Scale Solar PV Project that have accelerated RE installed capacity and power generation significantly.

Table 1 below provides a summary of energy and RE policy development in Malaysia: 
Renewable Energy (RE) and Theory on Business Sustainability: Malaysia Policy Development

Table I. The Development of Policies in Malaysia

\begin{tabular}{|c|c|c|}
\hline Year & Policy and Act & Description (Initiatives, Programs and Activities) \\
\hline 1966 & Petroleum Mining Act & \\
\hline 1974 & Petroleum Development Act & Establishment of Petroliam Nasional Berhad (PETRONAS) \\
\hline 1975 & National Petroleum Policy & \\
\hline 1979 & National Energy Policy & \\
\hline 1980 & National Depletion Policy & Photovoltaic (PV) System for Rural Electrification Program \\
\hline 1981 & Four Fuel Diversification Policy & \\
\hline 1986 & Science \& Technology Policy & Photovoltaic Grid Connected System Application (First introduce) (1998) \\
\hline 2000 & Five Fuel Diversification Policy & $\begin{array}{l}\text { Projects and Initiatives: } \\
\text {-Five Fuel Diversification Strategy (2000) } \\
\text {-Centre for Education, Training and Research in Renewable Energy, Energy } \\
\text { Efficiency and Green Technology (CETREE \& GT) (2000) } \\
\text {-Small Renewable Energy Power (SREP) (2001) }\end{array}$ \\
\hline 2002 & Environmental Policy* & $\begin{array}{l}\text { Continue Projects and Initiative: } \\
\text {-Biomass Power Generation and Generation Project (BioGen) (2002) } \\
\text {-Malaysia Building Integrated Photovoltaic Project (MBIPV) (2005) }\end{array}$ \\
\hline 2006 & National Biofuel Policy & $\begin{array}{l}\text { Programs: } \\
\text {-B5 biodiesel program } \\
\text {-B7 biodiesel program } \\
\text {-B10 biodiesel program } \\
\text {-B20 biodiesel program }\end{array}$ \\
\hline 2007 & National Biofuel Industry Act & \\
\hline \multirow[t]{2}{*}{2009} & National Green Technology Policy & Green Technology Financing Scheme \\
\hline & National Climate Change Policy* & \\
\hline \multirow[t]{4}{*}{2010} & $\begin{array}{l}\text { National Renewable Energy Policy and } \\
\text { Action Plan }\end{array}$ & $\begin{array}{l}\text { Renewable Energy Initiatives: } \\
\text {-Pioneer Status (PS) } \\
\text {-Investment Tax Allowance (ITA) } \\
\text {-Green Technology Financing Scheme (GTFS) } \\
\text {-Renewable Energy Business Fund (REBF) }\end{array}$ \\
\hline & Renewable Energy Act & \\
\hline & New Energy Policy & \\
\hline & National Energy Efficiency Action Plan & \\
\hline \multirow[t]{2}{*}{2011} & Sustainable Energy Development Act & $\begin{array}{l}\text { Established Sustainable Energy Development Authority (SEDA) } \\
\text { Renewable Energy Schemes and Initiatives: } \\
\text {-Renewable Energy and Energy Efficiency Scheme } \\
\text {-Feed in Tariff (FiT) Scheme (2011) } \\
\text {-Net Energy Metering Scheme (2016) } \\
\text {-Large Scale Solar PV Project (2016) }\end{array}$ \\
\hline & National Biomass Strategy 2020 & \\
\hline \multirow[t]{2}{*}{2017} & Transformasi Nasional 50 (TN50) & \\
\hline & $\begin{array}{l}\text { National Green Technology Masterplan } \\
2017-2030\end{array}$ & $\begin{array}{l}\text { Latest framework aligns strategic goals to MP11 target. To facilitate the } \\
\text { mainstreaming of green technology encompassing the four pillars set in NGTP. }\end{array}$ \\
\hline
\end{tabular}

Source: Adopted and adapted from [36]-[37].

Moving forward, a strong policy is needed to tackle the challenges in meeting the demand, energy security and also the affordability of energy pricing. Thus, in energy security dimension, perhaps the government should put attention on $\mathrm{RE}$ by engaging more on the alternative mechanism to deploy RE capacity through program such as Large-Scale Solar PV, Net Metering as at current practices and also other new initiative like green certificates. The exploration on new $\mathrm{RE}$ resources such as wind, geothermal, ocean thermal energy conversion (OTEC) also could assist in building up new opportunities to enlarge the share of RE in the energy mix and ensure the future energy security [38]. Realizing the importance of energy as a vital dimension in economic and social development, the government of Malaysia should continuously review its energy policy and practices to ensure long-term sustainability, reliability and security of energy supply [39].

\section{Conclusion}

The energy industry is changing fast in multiple directions. It is also regularly known as the catalyst for development in a country. Malaysia's energy policy seems to face a number of challenges, particularly a fragmented policy view on its aspiration to reach the target of $20 \%$ renewable energy matrix by 2025 . Among the ways forward for RE development is by introducing appropriate RE policies inclusively to support multiple level individual, market players, industries, business and community.

\section{ACKNOWLEDGEMENT}

This research work is supported by the Universiti Tenaga Nasional Internal Grant (UNIIG2018), Project code: J510050852. 


\section{REFERENCES}

1. G. Marin, "a Comparative Study on the European Renewable Energy Sources Facing Globalization," Manag. Mark., vol. 8, no. 4, 2013, pp. 723-746.

2. P. D. Lund, "Effects of energy policies on industry expansion in renewable energy," Renew. Energy, vol. 34, no. 1, 2009, pp. 53-64.

3. A. Masini and E. Menichetti, "The impact of behavioural factors in the renewable energy investment decision making process: Conceptual framework and empirical findings," Energy Policy, vol. 40, no. 1 , 2012, pp. 28-38.

4. R. D. Chang, J. Zuo, Z. Y. Zhao, G. Zillante, X. L. Gan, and V. Soebarto, "Evolving theories of sustainability and firms: History, future directions and implications for renewable energy research,' Renew. Sustain. Energy Rev., vol. 72, no. July 2017, pp. 48-56.

5. N. A. Bakar, H. Abdullah, F. W. Ibrahim, and M. R. M. Jali, "Green economy: Evaluation of Malaysian company environmental sustainability," Int. J. Energy Econ. Policy, vol. 7, no. 2, 2017, pp. 139-143.

6. P. del Río and M. Burguillo, "Assessing the impact of renewable energy deployment on local sustainability: Towards a theoretical framework," Renew. Sustain. Energy Rev., vol. 12, no. 5, 2008, pp. 1325-1344.

7. A. Kumar et al., "A review of multi criteria decision making (MCDM) towards sustainable renewable energy development," Renew. Sustain. Energy Rev., vol. 69, no. October 2016, pp. 596-609.

8. S. M. Lele, "Sutainable development-acriticalreview," World Dev., vol. 19 , no. 6, 1991, pp. 607-621.

9. S. R. Abdulrazak and F. S. Ahmad, "Sustainable Development: A Malaysian Perspective," Procedia - Soc. Behav. Sci., vol. 164, no. August, 2014, pp. 237-241.

10. P. Johnston, M. Everard, D. Santillo, and K. Robèrt, "Reclaiming the definition of Sustainability," Environ. Sci. Pollut. Res., vol. 14, no. 1, 2007, pp. 60-66.

11. W. Beckerman, “Sustainable Development': Is It a Useful Concept?," in The Economics of Sustainability, Routledge, 1994, pp. 161-179.

12. P. Bansal, "The corporate challenges of sustainable development.," Acad. Manag. Exec., vol. 16, no. 2, 2011, pp. 122-131.

13. H. Bowen and F. Jonhson, Social Responsibility of Businessman., Harper. New York, 1953.

14. S. Pätäri, H. Arminen, A. Tuppura, and A. Jantunen, "Competitive and responsible? the relationship between corporate social and financial performance in the energy sector," Renew. Sustain. Energy Rev., vol. 37, 2014, pp. 142-154.

15. M. Orlitzky, F. L. Schmidt, S. L. Rynes, and S. L. Rynes, "Corporate Social and Financial Performance: A Meta-Analysis," Organ. Stud. vol. 24, no. March, 2003, pp. 403-441.

16. R. Barkemeyer, D. Holt, L. Preuss, and S. Tsang, "What happened to the 'development' in sustainable development? Business guidelines two decades after Brundtland," Sustain. Dev., vol. 22, no. 1, 2014, pp. 15-32.

17. M. J. Polonsky, "A stakeholder theory approach to designing environmental marketing strategy," J. Bus. Ind. Mark., vol. 10, no. 3, 1995, pp. 29-46.

18. R. Freeman, Strategic Management: A Stakeholder Approach - R. Edward Freeman - Google Books, Pitman. Boston, 1984.

19. B. Agle, R. Mitchell, and J. Sonnenfeld, "Who matters to CEOs? An investigation of stakeholder attributes and salience," Acad. Manag. J. vol. 42 , no. 5, 1999 , pp. 507-525.

20. M. K. Linnenluecke and A. Griffiths, "Firms and sustainability: Mapping the intellectual origins and structure of the corporate sustainability field," Glob. Environ. Chang., vol. 23, no. 1, 2013. pp. 382-391.

21. E. M. Nfah and J. M. Ngundam, "Identification of stakeholders for sustainable renewable energy applications in Cameroon," Renew. Sustain. Energy Rev., vol. 16, no. 7, 2012, pp. 4661-4666.

22. WCED, World Commission on Environment and Development.Our common future. Oxford University Press, 1987.

23. I. Montiel and J. Delgado-Ceballos, "Defining and Measuring Corporate Sustainability: Are We There Yet?," Organ. Environ., vol. 27, no. 2, 2014, pp. 113-139.

24. M. Werre, "Van Marrewijk \& Werre, 2003," 2003, pp. 107-119.

25. T. Artiach, D. Lee, D. Nelson, and J. Walker, "The determinants of corporate sustainability performance," Account. Financ., vol. 50, no. 1, 2010, pp. 31-51.

26. J. Elkington, Cannibals with forks: the triple bottom line of 21st century business., Capstone. Oxford, 1997.

27. D. Jamali, "Insights into triple bottom line integration from a learning organization perspective," Bus. Process Manag. J., vol. 12, no. 6 , 2015, pp. 809-821.
28. M. Melissa J. and D. Lenita, "Exploring future competitive advantage through sustainable supply chains," Int. J. Phys. Distrib. Logist. Manag., vol. 37, no. 9, 2007, pp. 763-774.

29. R. Gray, "Is accounting for sustainability actually accounting for sustainability...and how would we know? An exploration of narratives of organisations and the planet," Accounting, Organ. Soc., vol. 35, no. 1, 2010, pp. 47-62.

30. OECD, Organization Economic Co-operation and Development "Towards Green Growth." 1999.

31. J. O. Petinrin and M. Shaaban, "Renewable energy for continuous energy sustainability in Malaysia," Renew. Sustain. Energy Rev., vol. 50, 2015, pp. 967-981.

32. EPU, Economic Planning Unit, "Chapter 6: Pursuing green growth for sustainability and resilience (Eleventh Malaysia Plan)," in Rancangan Malaysia Kesebelas (Eleventh Malaysia Plan) : 2016-2020, 2015, p 17.

33. UNEP, United Nations Environment Programme. "Pathways to Sustainable Development and Poverty Eradication - A Synthesis for Policy Makers." 2011.

34. Y. Ge and Q. Zhi, "Literature review: The green economy, clean energy policy and employment," Energy Procedia, vol. 88, 2016, pp. 257-264.

35. SEDA, Sustainable Energy Development Authority, "Sustainable Energy Malaysia Dawn of A New Era," 2008.

36. H. Hashim and W. S. Ho, "Renewable energy policies and initiatives for a sustainable energy future in Malaysia," Renew. Sustain. Energy Rev., vol. 15, no. 9, 2011, pp. 4780-4787.

37. KeTTHA, Ministry of Energy, Green Technology and Water. National Renewable Energy Policy \& Action Plan, 2008.

38. UNDP, United Nations Development Programme. Energy and Poverty in Malaysia: Challenges and the Way Forward. 2007.

39. A. R. Mohamed and K. T. Lee, "Energy for sustainable development in Malaysia: Energy policy and alternative energy," Energy Policy, vol 34, no. 15, 2006, pp. 2388-2397.

\section{AUTHORS PROFILE}

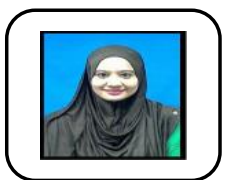

Zeittey Karmilla Kaman is currently the Head of Energy \& Sustainability Unit at the Institute of Energy Policy and Research (IEPRe), UNITEN and Senior Lecturer at Universiti Tenaga Nasional (UNITEN). She holds a PhD in Business Management specializing in Corporate Socia Responsibility (CSR) \& Environmental Management from Universiti Malaysia Pahang, Master Degree in Business Law from University Kebangsaan Malaysia and Bachelor of Business Administration (Hons) from University Putra Malaysia. She has more than 17 years teaching experience at several colleges and UNITEN and had published numerous papers internationally and made presentations in both local and international forums. Her research specialization is in CSR, Energy Sustainability Policy and Environmental Management.

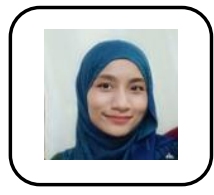

Siti Fatihah Salleh is currently a Post-Doctoral Researcher at Institute of Energy Policy and Research (IEPRe), Universiti Tenaga Nasional. She holds a PhD in Bioprocess Engineering from Universiti Sains Malaysia and Bachelor of Science in Chemical Engineering from Universiti Teknologi PETRONAS. Her research areas include renewable energy, energy efficiency and green building.

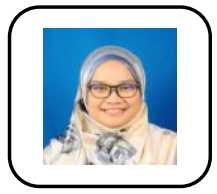

Waznatol Widad Mohamad Ishak is currently a research assistant at Institute of Energy Policy and Research (IEPRe), UNITEN. She holds a Master Degree in Science specializing in Energy Economics and Bachelor of Science in Actuarial Science and Risk Management from Universiti Sains Islam Malaysia, (USIM).Her research interest includes Renewable Energy, Econometric Modelling and Energy Economic. 